\title{
Water Pollution in India: Causes, Effects and Remedies - A Case Study
}

\author{
N. Sarubala, N. Nagarajan, S. Sivaprakasam and K. Karthikeyan \\ Department of Civil Engineering, Annamalai \\ University, Annamalai Nagar, India
}

\section{ABSTRACT}

Water contamination is the defilement of water bodies all the time by human activities. It occurs when pollutants are discharged directly into water bodies without enough treatment to get rid of harmful compounds. Pollutants get into water mainly by human causes or factors. Water pollution is one of the biggest issues facing India right now. As may be evident, untreated sewage is the biggest source of such form of pollution in India. There are other sources of pollution such as runoff from the agricultural sector as well as unregulated units that belong to the small-scale industry. The situation is so serious that perhaps there is no water body in India that is not polluted to some extent or the other. In fact, it is said that almost $80 \%$ of the waterbodies in India are highly polluted. Ganga and Yamuna are the most polluted rivers in India.

\section{KEY WORDS: CONTAMINATION, HUMAN HABITATION, WATER POLLUTION.}

\section{INTRODUCTION}

Water contamination is debased water, harmful to people or the climate. It happens when unsafe synthetic substances or microorganisms or now and again essentially trash or a lot of residue sullies a stream, waterway, lake, wetland, groundwater spring, sea, so, any waterway. Anthropogenic warm contrasts brought about by the release of high temp water from power plants and industrial facilities straightforwardly into an untamed water source is additionally viewed as water contamination as it diminishes oxygen levels and adjusts the species that can make due there, frequently welcoming non-local species attack, modifying the natural pecking order and regularly lessening species biodiversity. The

\section{ARTICLE INFORMATION}

Received 14th Oct 2020 Accepted after revision 23rd Dec 2020 Print ISSN: 0974-6455 Online ISSN: 2321-4007 CODEN: BBRCBA

Thomson Reuters ISI Web of Science Clarivate Analytics USA and Crossref Indexed Journal

\section{Clarivate
Analytics}

NAAS Journal Score 2020 (4.31)

A Society of Science and Nature Publication,

Bhopal India 2020. All rights reserved.

Online Contents Available at: http//www.bbrc.in/

Doi: $h$ ttp://dx.doi.org/10.21786/bbrc/13.15/53 sacred Ganges River takes the prize for the world's most polluted river, carrying sewage, trash, animal carcasses and wasted food.The single biggest reason for water pollution in India is urbanization at an uncontrolled rate. The treatment and disposal of wastewater has also been a major issue in this regard. The areas near rivers have seen plenty of towns and cities come up and this has also contributed to the growing intensity of problems.

Uncontrolled urbanization in these areas has also led to generation of sewage water. In the urban areas water is used for both industrial and domestic purposes from waterbodies such as rivers, lakes, streams, wells, and ponds. Worst still, $80 \%$ of the water that we use for our domestic purposes is passed out in the form of wastewater. In most of the cases, this water is not treated properly and as such it leads to tremendous pollution of surfacelevel freshwater.

2. Sources of Water Pollution: The two chief sources of water pollution can be seen as:

2.1 Point Source: Point sourcerefers to the pollutants that belong to a single source. An example of this would be emissions from factories into the water. Point source

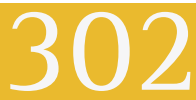


pollution refers to a contaminants that enter a waterway through a discrete conveyance, such as pipe or ditch. The Example for point source is the discharges from a sewage treatment plant, a factory and a city storm drain.

2.2 Non-Point Source: Non point refers to the pollutants emitted from multiple sources. Contaminated water after rains that has travelled through several regions may also be considered as a non-point source of water pollution. Non-point source pollution refers to diffuse contaminants that does not originate from a single discrete source. NPS pollution is often accumulative effect of small amounts of contaminants gathered from a large area.The leaching out of nitrogen compounds from agricultural land which has been fertilized is a typical example.

\section{Causes of Water Pollution:}

3.1 Agriculture and Nutrient Pollution: Around the world, agriculture is the leading cause of water degradation. Every time it rains, fertilizers, pesticides, and animal waste from farms and livestock operations wash nutrients and pathogens such bacteria and viruses into our waterways. Nutrient pollution, caused by excess nitrogen and phosphorus in water or air, is the numberone threat to water quality worldwide and can cause algal blooms, a toxic soup of blue-green algae that can be harmful to people and wildlife. Some waste water, fertilizers and sewage contain high levels of nutrients. If they end up in water bodies they encourage algae and weed growthin the water bodies, this will make the water undrinkable, and even clog filters. Too much algae will also use all the oxygen starvation

3.2 Sewage and Wastewater: Used water is wastewater. It comes from our sinks, showers, and toilets (think sewage) and from commercial, industrial, and agricultural activities (think metals, solvents, and toxic sludge). The term also includes storm water runoff, which occurs when rainfall carries road salts, oil, grease, chemicals, and debris from impermeable surfaces into our waterways.

3.3 Surface Water Pollution: Surface water includes natural water found on the earth's surface like rivers, lakes, lagoons and oceans. Hazardous substances coming into contact with this surface water, dissolving or mixing physically with the water can be called surface water pollution. For example, industriesemptying oil spills and chemical waste into water bodies are also key contributors.

3.4 Oxygen Depletion: Water bodies have microorganism. These include aerobic and anaerobic organisms, when too much biodegradable matter (things that easily decay) end up in water, it encourages more microorganisms growth, and they use up more oxygen in the water. If oxygen is depleted, aerobic organisms die, and anaerobic organisms grow more to produce harmful toxins such as ammonia, sulfides.

3.5 Ground Water Pollution: When humans apply pesticides and chemicals to soils, they are washed deep into the ground by rain water. This get to underground water, causing pollution underground. This means when we dig wells and bore holes to get water from underground, it needs to be treated before.

3.6 Oil Pollution by Oil Industries: Routine shipping, runoff and dumping of oils on the ocean surfaces happens every day. Oil spills cause majorproblems, and can be extremely harmful to local marine wildlife such as fish, birds and sea otters and other aquatic life. Because oil does not dissolve it stays on the water surface and suffocates fish. Oil also gets caught in the feathers of sea birds, making it difficult for them to fly. Some animals die as a result.

Figure 3.1: Causes of Water Pollution

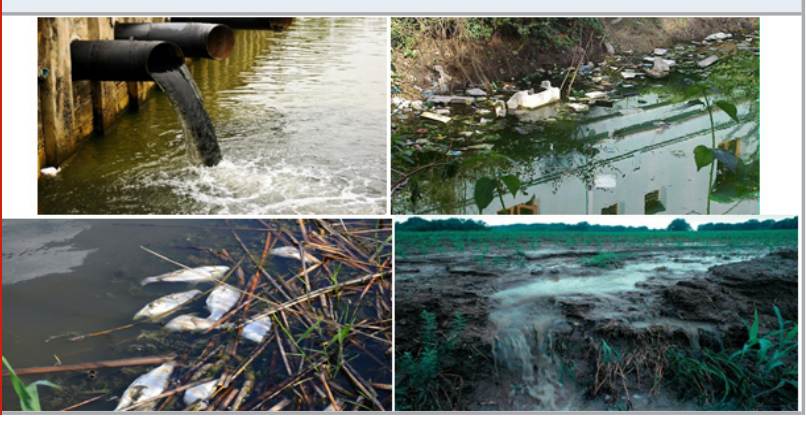

4. Effects of Water Pollution: In fact as far as India is concerned polluted water is one of the major factors behind the general low levels of health in India, especially in the rural areas. Polluted water can lead to diseases such as cholera, tuberculosis, dysentery, jaundice, diarrhea, etc. In fact, around 80\% stomach ailments in India happen because of consuming polluted water.Many water bodies near urban areas are highly polluted. This is the result of both the garbage dumped by individuals and dangerous chemicals legally and health centers, schools, market places. The Death of aquatic animals, Disruption of food chains, Diseases, Destruction of ecosystems and so on are some of the common effects of water pollution.

4.1 Human Health: We all drink water that comes from a source: this may be a lake or local river. In practice of poor screening and purification practices, people often get water-borne disease outbreaks such as cholera and tuberculosis. Every year, there are an estimated 3-5 million cholera cases and 100,000-120,000 deaths due to cholera. Take toxins emitted by algae growth for instance: this can cause stomach aches and rashes. Excess nitrogen in drinking water also poses serious risks to infants. EPA's 2010 National Lakes Assessment found that almost 20 per cent of the nation's lakes have high levels of nitrogen and phosphorus pollution. The report also showed that poor lake conditions related to nitrogen or phosphorus pollution doubled the likelihood of poor ecosystem health.

4.2 Ecosystems: Nutrient pollution from upstream often flow downhill and even travel miles into other larger water bodies. The effect is that it breeds algae growth and causes the growth of much more water organism. 
This algae attack affects fish and other aquatic animals by absorbing and reducing their oxygen supply.

4.3 Death of Animals: Animals, including water animals, die when water is poisoned for various reasons. Other animals are stressed and their populations are endangered. In a classic case of marine pollution in recent time, 16000 miles of a coastline was affected by an oil spill. That water pollution caused a lot of damage and deaths of many animals.Over 8,000 animals (birds, turtles, mammals) were reported dead just 6 months after the spill, including many that are already on the endangered species list. The immediate impact on the wildlife includes oil-coated birds and sea turtles, mammal ingestion of oil, and dead or dying deep-sea coral

4.4 Economic Cost: From the above, it is evident that there are some real financial implications that will result from water pollution. It can cost a lot more to purify drinking water that takes its source from nutrientpolluted water bodies. Fishing stock is affected negatively when there is a depletion of oxygen. Consumers are also worry of fish from these sources and tend to stay away from them, costing fisheries to lose revenue. In places where there are water activities or sports, lots of money is spent to clean up the water from algae blooms and the like.

\section{Treatments Involved To Control Water Pollution}

5.1 Primary Treatment: Primary treatment of wastewater involves sedimentation of solid waste within the water. This is done after filtering out larger contaminants within the water. Wastewater is passed through several tanks and filters that separate water from contaminants. The resulting "sludge" is then fed into a digester, in which further processing takes place. This primary batch of sludge contains nearly 50\% of suspended solids within wastewater. It includes:

Screening and Pumping: The incoming wastewater passes through screening equipment where objects such as rags, wood fragments, plastics, and grease are removed. The material removed is washed and pressed and disposed of in a landfill. The screened wastewater is then pumped to the next step: grit removal.

Grit Removal: In this step, heavy but fine material such as sand and gravel is removed from the wastewater. This material is also disposed of in a landfill.

Primary Settling: The material, which will settle, but at a slower rate than step two, is taken out using large circular tanks called clarifiers. The settled material, called primary sludge, is pumped off the bottom and the wastewater exits the tank from the top. Floating debris such as grease is skimmed off the top and sent with the settled material to digesters.

5.2 Secondary Treatment: Secondary treatment of wastewater makes use of oxidation to further purify wastewater. It includes
Aeration / Activated Sludge: In this step, the wastewater receives most of its treatment through biological degradation, the pollutants are consumed by microorganisms and transformed into cell tissue, water, and nitrogen. The biological activity occurring in this step is very similar to what occurs at the bottom of lakes and rivers, but in these areas the degradation takes years to accomplish.

Secondary Settling: Large circular tanks called secondary clarifiers allow the treated wastewater to separate from the biology from the aeration tanks at this step, yielding an effluent, which is now over 90\% treated. The biology (activated sludge) is continuously pumped from the bottom of the clarifiers and returned to the aeration tanks in step four.

Filtration: The clarified effluent is polished in this step by filtering through 10 micron polyester media. The material captured on the surface of the disc filters is periodically backwashed and returned to the head of the plant for treatment.

5.3 Tertiary Treatment: Tertiary treatment is the final cleaning process that improves wastewater quality before it is reused, recycled or discharged to the environment. It includes:

Disinfection: To assure the treated wastewater is virtually free of bacteria, ultraviolet disinfection is used after the filtration step. The ultraviolet treatment process kills remaining bacteria to levels within our discharge permit.

Oxygen Uptake: The treated water, now in a much stabilized high quality state, is aerated if necessary to bring the dissolved oxygen up to permit level. After this step, the treated water passes through the effluent outfall where it joins the River. Pollutant removal is maintained at $98 \%$ or greater.

\section{Prevention of Water Pollution}

- Never throw rubbish away anyhow. Always look for the correct waste bin. If there is none around, please take it home and put it in your trash can. This includes places like the beach, river.

- Use water wisely, do not keep the tap running when not in use. Also, you can reduce the amount of water use in bathing and washing. If we all do this, we can significantly prevent water shortages and reduce the amount of dirty water that needs treatment.

- Don't throw chemicals, oils and medicines down the sink drain or the toilet, in any cities your local environment office can help with the disposal of medicines and chemicals.

- $\quad$ Buy more environmentally safe cleaning liquids for use at home and other public places they are less dangerous to the environment

- If you use chemicals and pesticides for our gardens and farms, be mindful not to overuse pesticides and fertilizers. This will reduce runoff of the chemical into nearby water sources. Start looking at options 
of composting and using organic manure instead

- If you live close to a water body, try to plant lots of trees and flowers around your home, so that when it rains, chemicals from your home does not easily drain into the water.

\subsection{Things You Can Do To Reduce Water Pollution}

- Do not pour fat from cooking or any other type of fat, oil, grease down the sink.Keep a fat jar under the sink to collect the fat and discard in the solid waste when full

- Do not dispose of house hold chemicals or cleaning agents down the sink or toilet

- Do not flush pills, liquids or powder medications or drugs down the toilet.For recommendations on paper disposal for all types of medicals wastes

- Avoid using the toilet as waste basket. Most tissues, wrappers, dust clothes and other paper goods should be properly discarded in a waste basket

- Use the minimum amount of detergents and or bleech when you are washing clothes or disposals. Use phosphate free soaps and detergents

- If your home has a sump pump or cellar drain, make certain it does not drain into the sanitary sewer system.

- Minimize the use of pesticides, herbicides, fertilizers. Do not dispose of these chemicals, motor oil, or other automotive fluids into the sanitary sewer systems. Both of them end at the river

- $\quad$ Avoid using a garbage disposal. Keep solid wastes solid. Make a compost pile from vegetable scraps

\section{CONCLUSION}

The first major solution in this context is conservation of soil. Soil erosion can contribute to water pollution. So, if soil can be conserved we can prevent water pollution too. We can follow measures such as planting more trees, managing erosion in a better way, and use farming methods that are better for the soil. In the same vein it is also important to follow the right methods in disposing toxic waste. For starters, we can use products that have lesser amounts of volatile organic compounds in them. Even in cases where toxic material like paints, cleaning supplies, and stain removers are used, they need to be disposed of in the right way. It is also important to look into oil leaks in one's cars and machines.Cleaning up waterways and beaches, avoiding the usage of nonbiodegradable material like plastic, and being more involved in various measures pertaining to preventing water pollution.

\section{REFERENCES}

Anil .k Dwivedi,"Researches in Water Pollution - A Review”, ISSN- (2349 - 4077) vol.4, Isuue - 1, Jan 2017.

Central Board for the Prevention and Control of Water Pollution. 1979. Waste Water Collection Treatment and Disposal in Class I Cities

Garg Mukesh , "water pollution in India causes and remedies”, ISSN: 2249-5894,vol.2, issue 6,2012

Hari Kishore, water pollution and treatment technologies.

Leonard, Jeffrey and Morell, David. 1981. "Emergence of environmental concern in developing countries: a political perspective”. Stanford J. International Law, 17: 231

Lester, James P. and Bowman, Ann 0., eds. 1983. The Politics of Hazardous Waste Management, Durham: Duke University.

Meenakshi k. Changte, "water pollution in India causes and remedies”, IJSR vol.4, issue 8, August 2015

Oswald, w.j., Introduction to advanced wastewater ponding systems.

Royal Edwards Williams et al., "water pollution in India - an overview”, ISSN: 2320 - 4168, vol.6, issue 5, February 2018

Williams, Bruce A. and Matheny, A. R. 1984. “Testing theories of social regulation: hazardous waste regulation in the American States”. J. Politics, 46(2): 428-458. 